\title{
IL-4 inhibits apoptosis and prevents mitochondrial damage without inducing the switch to necrosis observed with caspase inhibitors
}

\author{
Christophe Lemaire ${ }^{1}$, Karine Andréau ${ }^{1}$, \\ Carole Sidoti-de Fraisse ${ }^{2}$, Arlette Adam ${ }^{1}$ and \\ Vongthip Souvannavong ${ }^{*, 1}$ \\ 1 Institut de Biochimie, CNRS UMR 8619, Université Paris-Sud, 91405 Orsay, \\ France \\ 2 CGM, CNRS, Avenue de la Terrasse, 91198 Gif sur Yvette, France \\ * corresponding author: V Souvannavong, CNRS UMR 8619, Bât 430, \\ Université Paris-Sud, 91405 Orsay Cedex, France. tel: 331691548 46; \\ fax: 331698537 15; e-mail: vongthip.souvannavong@bbmpc.u-psud.fr
}

Received 18.2.99; revised 2.5.99; acepted 21. 6.99 Edited by J. Reed

\begin{abstract}
We previously demonstrated that the broad-spectrum caspase inhibitor, zVAD-fmk, totally deviated apoptosis to necrosis in $B$ lymphocytes. We report here that, in contrast with ZVAD-fmk, IL-4 protected B cells from spontaneous and from dexamethasone-induced apoptosis and actually maintained cell viability. This was assessed by morphological and biochemical criteria and accompanied by the maintenance of mitochondrial transmembrane potential $(\Delta \Psi \mathrm{m})$ and elevated glutathione (GSH) levels. Under these conditions, zVAD-fmk also totally inhibited apoptosis in thymocytes, but it partly preserved cell viability with a parallel increase in the percentage of cells exhibiting high $\Delta \Psi \mathrm{m}$ and elevated GSH levels. Nevertheless, non-rescued cells were deviated to necrosis. Therefore, the pathway leading to either apoptosis or necrosis appears to involve common mitochondrial dysfunctions which could not be reversed by caspase inhibition, suggesting that the pharmacological inhibition of cell death should occur at an earlier stage.
\end{abstract}

Keywords: apoptosis; necrosis; mitochondria; interleukin-4; dexamethasone; murine $B$ cells

Abbreviations: DAPI, 6-diamidino-2-phenylindol; DEX, dexamethasone; $\mathrm{DiOC}_{6}(3), 3,3$-dihexyloxacarbocyanine iodide; $\mathrm{EtBr}$, ethidium bromide; FDA, fluorescein diacetate; GSH, glutathione; $\mathrm{H}_{2} \mathrm{O}_{2}$, hydrogen peroxide; IL-4, interleukin-4; $\Delta \Psi \mathrm{m}$, mitochondrial transmembrane potential; MCB, monochlorobimane; zVAD-fmk, benzyloxycarbonyl-Val-Ala-Asp-(OMe)-fluoromethylketone

\section{Introduction}

Apoptosis, considered as the physiological form of cell demise, as opposed to necrosis or accidental cell death, is a fundamental feature of living cells. ${ }^{1}$ Apoptosis is essential to normal development and tissue homeostasis and is thus critical to the function of the immune system. ${ }^{2,3}$ Apoptotic cell death is characterized by morphological features, including reduction in cell volume, chromatin condensation, and nuclear DNA fragmentation, and is thus distinct from necrotic cell death. ${ }^{3-6}$

Apoptosis is linked to activation of cysteine proteases, with aspartate specificity, belonging to the family of caspases. $^{7,8}$ Since inappropriate or defective apoptosis is the cause of many diseases, ${ }^{9}$ the therapeutic potential of caspase inhibition is being explored. ${ }^{10}$

In addition to caspase activation, mitochondria appear to play a key role in the control of apoptotic cell death. ${ }^{11-13}$ However the sequence of changes that occur in the initial steps of apoptosis has not been clearly elucidated and, according to the experimental system used, the translocation of cytochrome $c$ from mitochondria to cytosol ${ }^{14}$ and/or induction of the mitochondrial permeability transition, which causes the loss of the mitochondrial membrane transmembrane potential $(\Delta \Psi \mathrm{m})$, have been reported to be critical in the apoptotic pathway. ${ }^{15,16}$

Peptide inhibitors, designed to mimic known sequences of caspase substrates, are currently used to suppress apoptosis. Recently, the long-term consequences of caspase inhibition have been investigated leading to contradictory results on whether the death process is completely prevented, or only delayed ${ }^{17-19}$ and even deviated to another form of cell death. ${ }^{20-22}$

Mature $\mathrm{B}$ lymphocytes undergo apoptosis in vitro, ${ }^{23}$ a process that can be increased by a variety of treatments or regulated by inhibition of some signalling pathways and activation of several cell surface molecules, including IL-4 receptors. ${ }^{24} \mathrm{IL}-4$ was initially recognized as a viability factor and a growth cofactor for $\mathrm{B}$ cells. ${ }^{25}$ It has been observed to decrease apoptosis of cultured B splenocytes ${ }^{23,26,27}$ and leukemia cells, ${ }^{28}$ to prevent apoptosis induced by anti-lg treatment ${ }^{26,29}$ and to induce tolerance to anti-Fas mediated apoptosis. ${ }^{30}$

Recently, we found that the general caspase inhibitor, zVAD-fmk, effectively inhibited the main characteristic features of apoptosis while it failed to maintain cell viability, inducing a switch from apoptosis to necrosis in murine B lymphocytes undergoing spontaneous or druginduced apoptosis. ${ }^{21}$ A similar switch was observed in thymocytes undergoing drug-induced apoptosis. ${ }^{31}$

These findings, and the general observation that a given stimulus can induce either apoptosis or necrosis depending on the intensity of the insult, suggested that apoptotic and necrotic death share a common pathway, the final issue 
being dependent on caspases. Consistent with its inability to prevent cell death, we observed here that zVAD-fmk was unable to prevent the loss of $\Delta \Psi \mathrm{m}$ and the reduction in GSH levels associated with apoptosis. In contrast, the antiapoptotic interleukin, IL-4, could protect B cells from both apoptosis and from mitochondrial damage and led to an effective maintenance of cell viability. This indicated that the rescue from apoptosis should occur upstream of mitochondrial perturbations to avoid the commitment to another form of cell death.

\section{Results}

\section{IL-4 protects B cells from spontaneous and drug-induced apoptosis maintaining cell viability without inducing necrosis}

Mature splenic B cells can be induced in vitro to undergo apoptosis and can be protected from induction of apoptosis by a number of biochemically distinct stimuli. ${ }^{24}$ We previously observed that a broad-spectrum and irreversible inhibitor of caspases, zVAD-fmk (100 $\mu \mathrm{M})$, effectively protected B cells from apoptosis but not from cell death; in fact zVAD-fmk totally deviated the apoptotic form of cell death to necrosis. ${ }^{21}$ We therefore examined whether inhibition of apoptosis by IL-4 led to similar consequences on long term survival and cell death. We first defined its effect on spontaneous and on DEX-induced apoptosis. Cytometric analysis after DAPI staining showed that the time-dependent apoptosis of B lymphocytes (quantitated by sub-G1 DNA) which is occurring in culture was totally inhibited by zVAD-fmk and greatly reduced by IL-4 (Figure 1A). DEX-induced apoptosis of $B$ cells was similarly inhibited by zVAD-fmk and reduced by IL-4. IL-4 and zVAD-fmk inhibitory effects on $B$ cell apoptosis were confirmed by the electrophoretic pattern of DNA laddering (Figure 1B). Since activation of caspase-3-like proteases appears to be an essential step in the execution phase of apoptosis, ${ }^{32}$ we examined whether the modulation of apoptosis was associated with activation of DEVD-specific caspases, as assessed by hydrolysis of the specific DEVD-pNA substrate (Figure 1C). Data show that caspase activation occurring in cultured $B$ cells was increased by DEX, reduced by IL-4 and totally abrogated by the peptide inhibitor zVAD-fmk. Similarly, DEVDase activity of DEX-treated cells was reduced by IL-4 and totally inhibited by zVAD-fmk. Morphological observation of cells stained with FDA and $\mathrm{EtBr}$ (see 2.3) revealed that IL-4 actually protected $B$ cells from cell death since it reduced the number of apoptotic cells with a corresponding increase of normal living cells. In contrast, zVAD-fmk treatment only deviated the form of cell death leading to a total disappearance of apoptotic cells with a corresponding appearance of necrotic cells (Figure 1D). It must be stressed that necrotic cells have G0/G1 DNA content and thus could not be distinguished from normal diploid cells by cytometric analysis.

\section{IL-4, but not zVAD-fmk, increases $B$ cell viability and maintains $\triangle \Psi \mathrm{m}$ and GSH levels}

It has been proposed that mitochondrial perturbations constitute an early step in the apoptotic process. To gain insight into the mechanism of IL-4-induced protection against apoptosis, a cytometric analysis was performed to quantitate cell viability by FDA staining and to examine IL-4 effect on mitochondrial functions. $\Delta \Psi \mathrm{m}$ was measured by using the fluorochrome $\mathrm{DiOC}_{6}(3)$ and the reduction of $\mathrm{GSH}$ levels, which is associated with $\Delta \Psi \mathrm{m}$ dissipation and uncoupling of the respiratory chain, was determined by means of MCB.

More than $93 \%$ B cells were recorded as viable at the initiation of cultures (TO), as determined by FDA staining, and they presented high $\Delta \Psi \mathrm{m}$ and elevated GSH levels (Figure 2). Cells treated with $\mathrm{H}_{2} \mathrm{O}_{2}(1 \mathrm{mM})$ were used as a standard for necrosis. More than $95 \%$ of $\mathrm{H}_{2} \mathrm{O}_{2}$-treated cells were recorded as necrotic by morphological observation (data not shown); they also exhibited a total loss of viability (FDA staining), had low $\Delta \Psi \mathrm{m}$ and GSH levels (Figure 2). After $8 \mathrm{~h}$ of culture in medium, the loss of cell viability was already important and affected about $25 \%$ of cells. A good correlation was observed between the number of viable cells and that of cells scored as positive for $\Delta \Psi \mathrm{m}$ and for elevated GSH levels $(75,77$, and $76 \%$ respectively). Spontaneous death was essentially due to apoptosis, as determined by cytometric analysis (Figure 1A). In agreement with morphological observation, zVAD-fmk, which deviated apoptosis to necrosis, did not appear to modify cell viability, as determined by the three criteria. In contrast, IL-4 improved global cell viability (from 75-88\%), and increased the percentage of positive cells for $\Delta \Psi \mathrm{m}$ (from $77-86 \%$ ) and elevated GSH levels (from 76-84\%). Dexamethasone, within $8 \mathrm{~h}$, increased apoptosis to about $50 \%$ (Figure 1A) and its effect was associated with a parallel decrease in the number of viable cells and in the number of cells exhibiting normal $\Delta \Psi \mathrm{m}$ and elevated $\mathrm{GSH}$ levels (53 and 50\% respectively, Figure 2). As observed in the case of spontaneous apoptosis, zVAD-fmk failed to improve global cell viability as assessed by FDA staining, the non-viable cells 'saved' from apoptosis being characterized as necrotic by morphology. It also did not appear to counteract DEX effects on the decline of $\Delta \Psi \mathrm{m}$ and on the reduction of GSH levels. In contrast, IL-4 increased cell viability (from $50-76 \%$ ) with a parallel increase in the percentage of cells having normal $\Delta \Psi \mathrm{m}$ and high $\mathrm{GSH}$ levels (from $53-76 \%$ and from $50-73 \%$, respectively).

Cell size, as evaluated by forward light scatter, appeared to be decreased in apoptotic cells, as compared with living cells (positive cells for FDA staining and $\Delta \Psi \mathrm{m}$ ). However, forward light scatter could not be used as a criteria for necrosis in dead cells (dim cells for FDA staining and $\Delta \Psi \mathrm{m}$ assessment) since necrotic $\mathrm{H}_{2} \mathrm{O}_{2}$-treated cells did not exhibit a clear and homogeneous cell size increase.

To investigate whether the respective effects of IL-4 and zVAD-fmk were transient or long-lasting, cultures were measured after $24 \mathrm{~h}$ (Figure 3). By that time about $40 \%$ of $B$ cells were characterized as apoptotic by cytometric analysis of DNA content, and less than $5 \%$ necrotic cells could be morphologically detected (see legend under Figure 3). As previously observed at $8 \mathrm{~h}$, IL-4 decreased both spontaneous and DEX-induced apoptosis with a corresponding increase of cell viability (Figure $3 \mathrm{~A}$ ) and a parallel increase in the percentage of cells positive for $\Delta \Psi \mathrm{m}$ (Figure $3 \mathrm{~B}$ ) and $\mathrm{GSH}$ levels 
(Figure 3C). In contrast, zVAD-fmk was almost devoid of any effect on global cell viability, on $\Delta \Psi \mathrm{m}$ and on GSH levels (Figure $3 A-C$ ), the loss of apoptotic cells being compensated by the appearance of an equivalent percentage of necrotic cells. Again, necrotic cells
(>95\% in $\mathrm{H}_{2} \mathrm{O}_{2}$-treated cells) appeared as non-viable (FDA staining and morphology) and non-apoptotic (cytometric analysis of DNA content and Figure 3A) and were recorded as negative for $\Delta \Psi \mathrm{m}$ (Figure $3 \mathrm{~B}$ ) and GSH levels (Figure 3C).

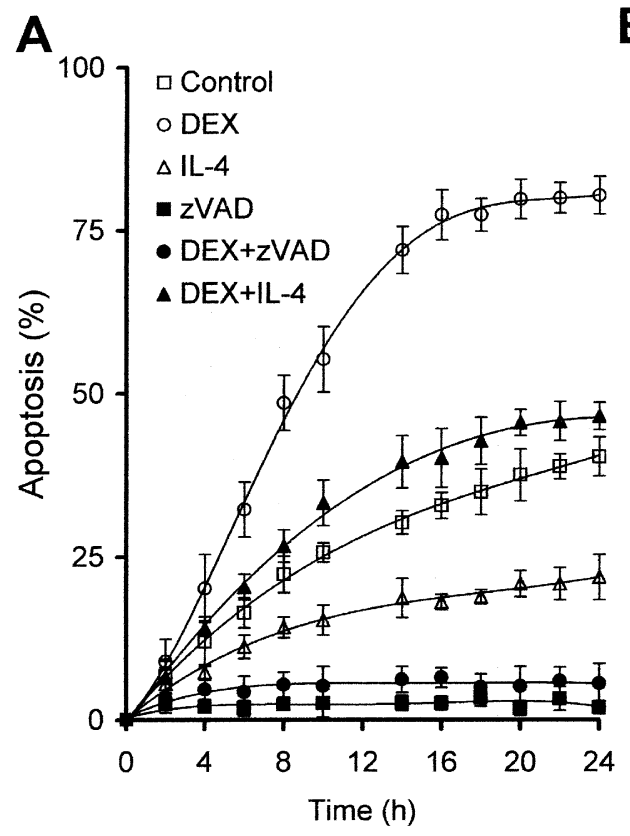

B
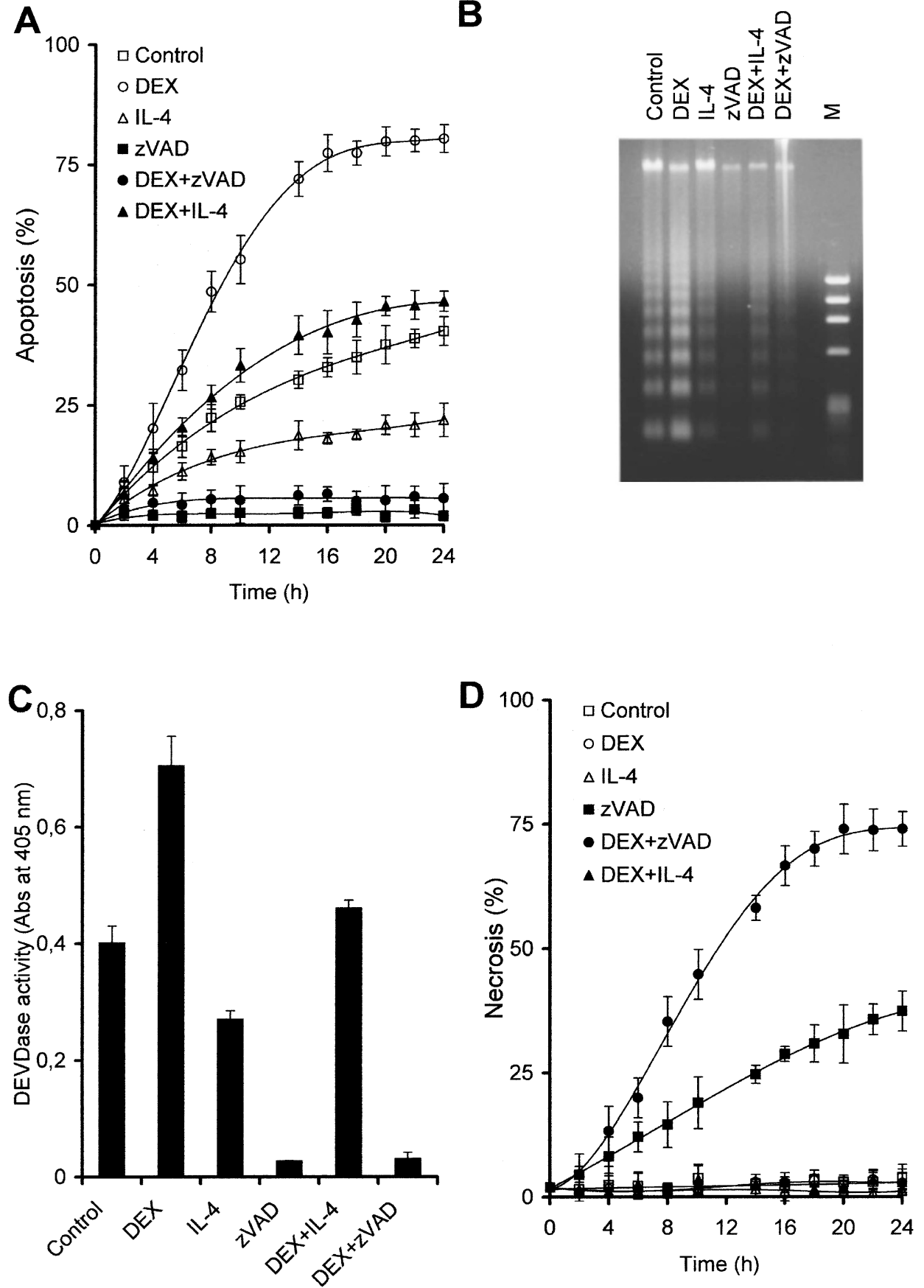

Figure 1 Comparative effects of zVAD-fmk and IL-4 on B lymphocyte apoptosis and necrosis. B lymphocytes $\left(5 \times 10^{5}\right.$ cells ml $\left.^{-1}\right)$ were incubated for various times, with or without dexamethasone (DEX, $5 \mathrm{nM}$ ), in the absence or the presence of ZVAD-fmk $(100 \mu \mathrm{M})$ or IL-4 (100 U/ml) as indicated. (A) Apoptosis was determined using cytometry and the DNA probe DAPI as the frequency of the sub-G1 cell population. (B) Agarose gel electrophoresis of DNA extracted from B lymphocytes cultured for $24 \mathrm{~h}$ in the absence or the presence of zVAD-fmk or IL-4 with or without DEX, lane M: $\phi \mathrm{X} 174 \mathrm{RF} /$ Haelll digest used as DNA size marker. (C) Caspase-3-like activity in B cells $\left(5 \times 10^{6}\right)$ cultured for $8 \mathrm{~h}$ with or without DEX in the presence or the absence of ZVAD-fmk or IL-4 was assessed by hydrolysis of DEVD-pNA substrate measured after $10 \mathrm{~h}$ at $405 \mathrm{~nm}$. (D) Quantitation of necrosis was performed by counting cells cultured in the conditions indicated for (A) after double staining with FDA and EtBr as described in Materials and Methods 


\section{zVAD-fmk inhibits apoptosis in thymocytes with a progressive shift to necrosis}

To determine whether these findings could be extended to another cell type, thymocytes undergoing spontaneous or DEX-induced apoptosis were cultured in the presence or in the absence of IL-4 or zVAD-fmk and analyzed by morphological examination and flow cytometry for global cell viability, mitochondrial functions and analysis of DNA content. IL-4 was devoid of any effect on the apoptosis of thymocytes and inhibition of caspases by zVAD-fmk initially led, after $6 \mathrm{~h}$, to a rescue from apoptosis with an increase of cell viability (data not shown). After $24 \mathrm{~h}$ the percentage of thymocytes undergoing spontaneous apoptosis was of $44 \%$, as estimated by sub-G1 DNA content, and more than $50 \%$ cells were considered as viable according to FDA staining, high $\triangle \Psi m$ and elevated GSH levels (Figure $4 A-C$ ). In the presence of zVAD-fmk, the number of viable cells and cells with high $\Delta \Psi \mathrm{m}$ and elevated GSH levels was increased to about $80 \%$, but the number of apoptotic cells was less than $5 \%$, thus suggesting the presence of $15 \%$ non-apoptotic dead cells. Indeed, these dead cells were identified as necrotic by morphologic examination (data not shown). Dexamethasone increased apoptosis to almost $90 \%$, as determined by DNA content with a parallel loss of FDA stainability and in the percentage of cells positive for $\triangle \Psi \mathrm{m}$ and GSH levels. As expected, zVADfmk totally abrogated DEX-induced apoptosis but, in contrast with results obtained in $\mathrm{B}$ cells, it led to a partial rescue since it prevented the loss of $\Delta \Psi \mathrm{m}$ and the reduction of GSH levels in about $50 \%$ of cells which were recorded as viable by FDA staining. Morphological examination revealed that the remaining non-viable and non-apoptotic cells were necrotic ( $40 \%$, data not shown). Only necrotic cells were detected, according to the four criteria, in $\mathrm{H}_{2} \mathrm{O}_{2}(1 \mathrm{mM})$-treated thymocytes.

\section{Discussion}

Caspase activation is essential in the apoptotic process but its inhibition is not always synonymous with increased cell life. Accordingly, the present study indicates that ZVAD-fmk failed to restore cell life of $B$ lymphocytes since it could only deviate the organized cell death process to necrosis, whereas similarly treated thymocytes could partly be saved. In contrast, IL-4 could effectively protect B cells from apoptosis and preserve cell viability at a premitochondrial stage.
Cell Viability

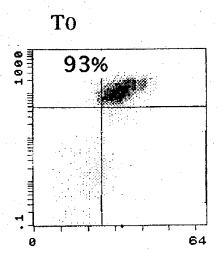

Control

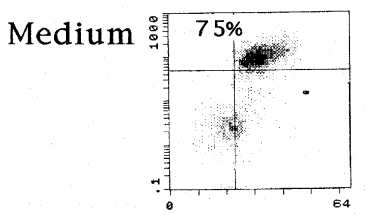

zVAD
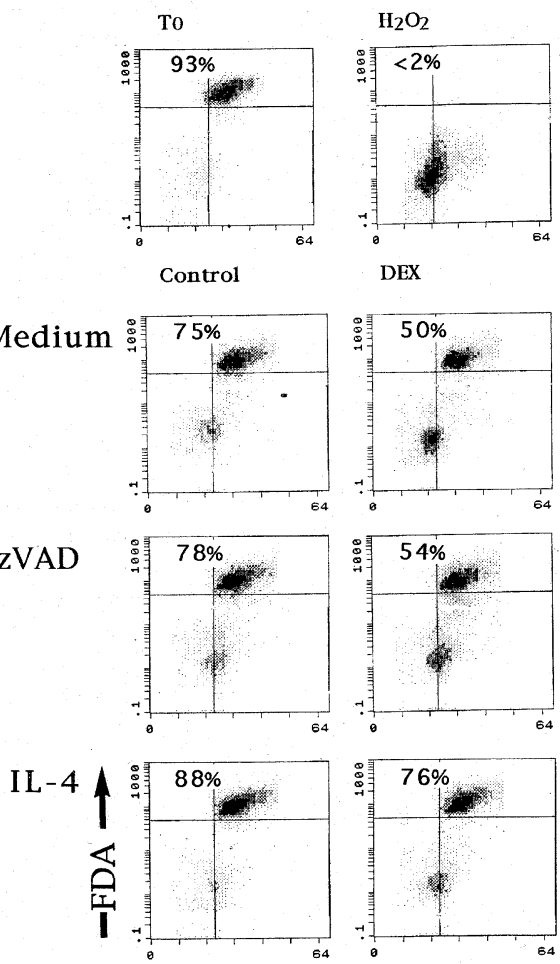

DEX
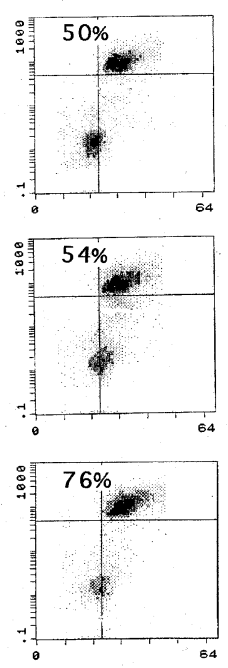

$\Delta \Psi \mathrm{m}$

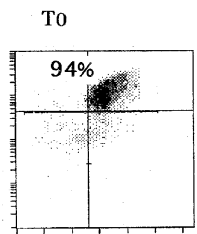

Control
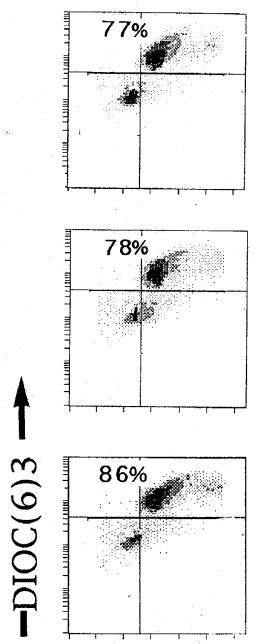

$\mathrm{H}_{2} \mathrm{O}_{2}$

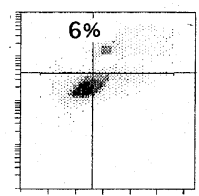

DEX
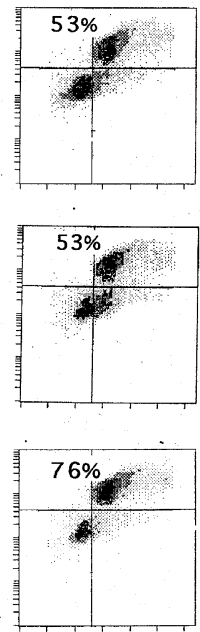

GSH

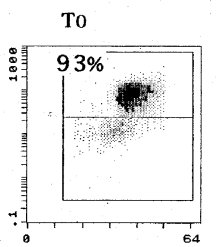

Control
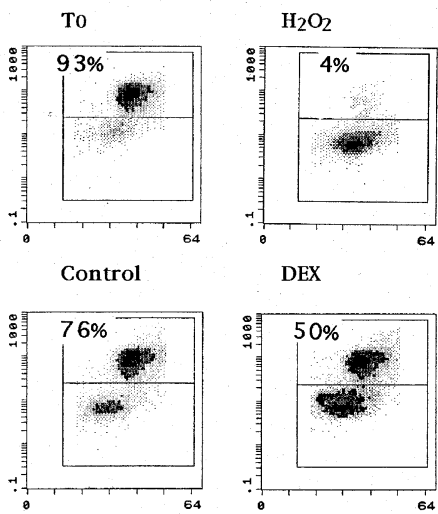

DEX
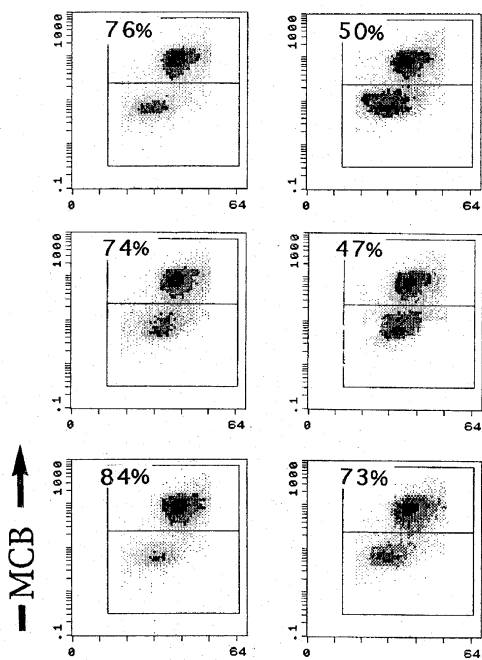

FALS (Cell Size)

Figure 2 Multiparametric flow cytometric analysis of viability markers. B lymphocytes at the initiation of cultures ( $\mathrm{T0}$ ) or cultured in the presence of $\mathrm{H}_{2} \mathrm{O}_{2}(1 \mathrm{mM})$ were used as standards. B cells were cultured $8 \mathrm{~h}$ without (control) or with dexamethasone (DEX) in medium or in the presence of $z \mathrm{VAD}$-fmk or IL-4, as indicated. Global cell viability was assessed by using FDA staining, mitochondrial potential $(\Delta \Psi \mathrm{m})$ by the cell permeant probe DiOC 6 ( 3$)$, and reduced glutathione levels (GSH) by the fluorochrome MCB (presented on ordinates, using a logarithmic scale), as described in Materials and methods. The forward angle light scatter is presented on abcissa (FALS on a linear scale). The percentage of cells scored as positive in each case, and delineated by an horizontal line, is presented on cytograms. These data are representative of at least three individual experiments 
A
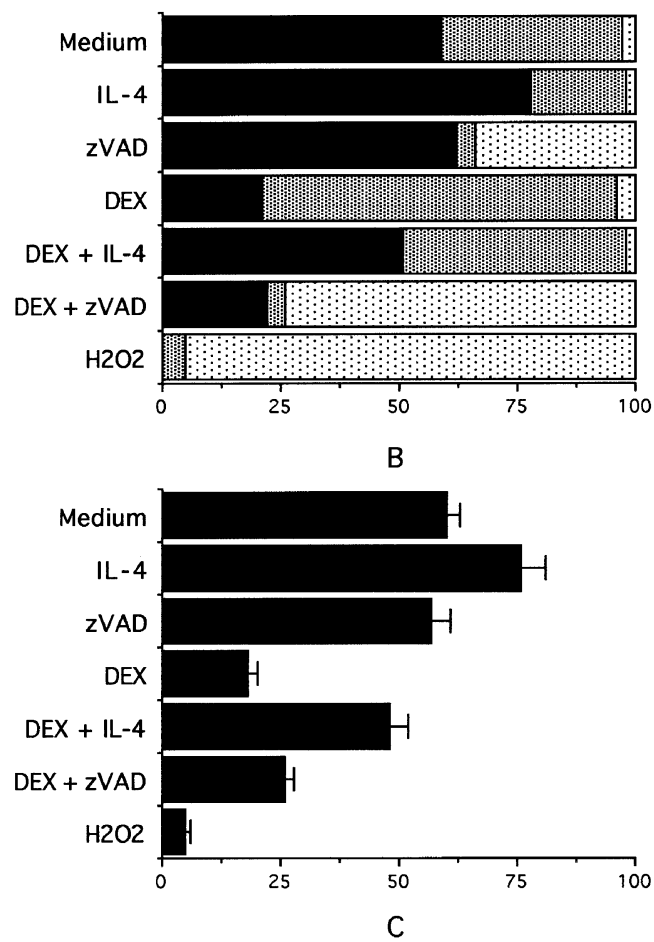

$\operatorname{DiOC6}(3)+$

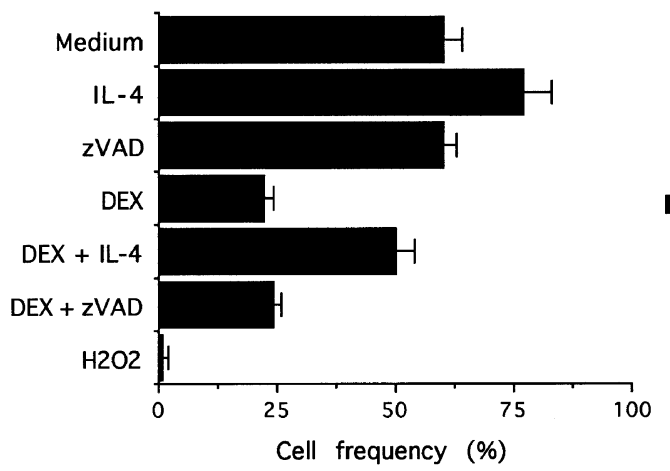

Figure 3 Influence of ZVAD-fmk and IL-4 on the progression to apoptosis or to necrosis of $B$ lymphocytes cultured $24 \mathrm{~h}$ with or without DEX. (A) The percentage of viable cells and of apoptotic cells was determined by cytometric analysis after staining with DAPI and FDA respectively. The difference between the percentage of dead cells (FDA negative) and that of apoptotic cells (sub-G1 DNA content) was due to the presence of necrotic cells as confirmed by morphological examination and quantitated as described in Materials and methods. (B) Percentage of cells presenting high $\Delta \Psi \mathrm{m}$ and scored as positive by cytometric analysis of $\mathrm{DiOC}_{6}(3)$. (C) Percentage of cells presenting high GSH levels as determined by cytometric analysis of MCB. $\mathrm{H}_{2} \mathrm{O}_{2}$-treated cells were used as a standard for necrosis

The molecular mechanism by which IL-4 protects B cells from apoptosis appears to be complex and is under study. A recent report has defined two separate mechanisms of action, one that is dependent on the insulin receptor substrate/phosphatidylinositol-3-kinase (IRS/PI3K) pathway and one that is independent of this IRS/PI3K-dependent pathway. $^{33}$ Two different pathways were also found, downstream of IL-4 receptor triggering. Thus IL-4 was shown to prevent, or to act independently of, the down-
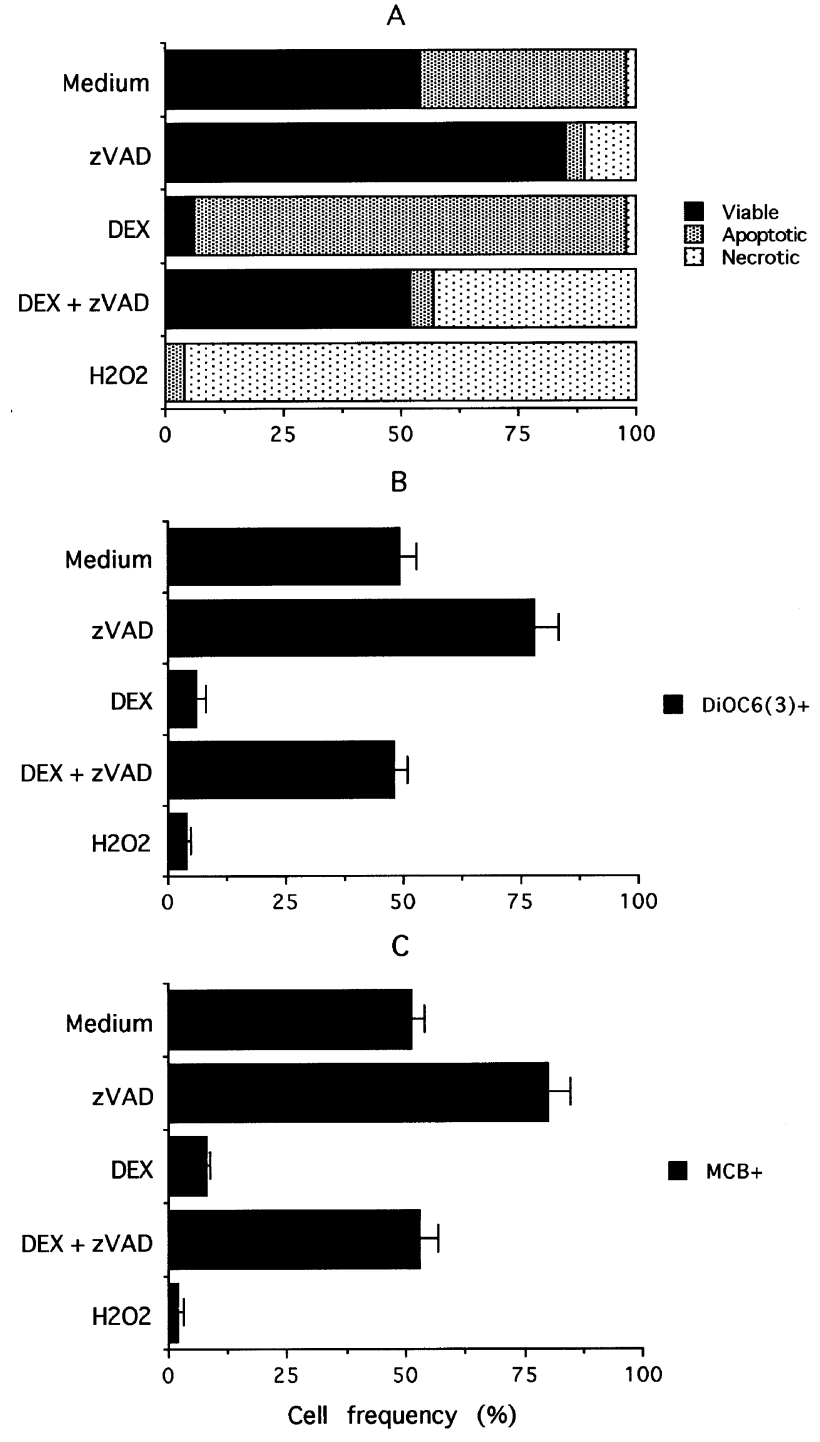

Figure 4 Influence of $z V A D-f m k$ on the progression to apoptosis or to necrosis of thymocytes. Cells were cultured as described for B cells in Figure 3 and analyses were performed at $24 \mathrm{~h}$

modulation of a $16 \mathrm{kDa}$ Bax-associated protein ('P16') which occurs during in vitro induction of apoptosis in mature B cells. It was suggested that the 'P16' downmodulation, and thus protection from apoptosis by IL-4, was an early event which did not require caspase activation. ${ }^{34}$ In agreement with an hypothesis on a rapid effect of IL-4, the present results indicate that IL-4 acted at an early stage, upstream of mitochondrial alterations, as shown by the maintenance of $\Delta \Psi \mathrm{m}$, and led to an actual abrogation of cell death. IL-4 inhibited also the reduction in GSH levels observed in cells undergoing spontaneous or drug-induced apoptosis. This is in agreement with previous findings showing that a decrease in intracellular GSH precedes the onset of apoptosis in thymocytes. ${ }^{35,36}$ It has been reported that inhibition of proteasomes, which act at a premitochondrial step, was effective in restoring cell viability, and thus 
the deviation towards another form of cell death. ${ }^{37}$ The possibility that IL-4 would inhibit proteasome activation is an hypothesis that is being explored.

Consistent with our previous findings on the total switch from apoptosis to necrosis upon treatment with zVADfmk, ${ }^{21}$ cytometric evaluation of global cell viability by FDA staining indicated that general caspase inhibition failed to protect $B$ cells against the commitment to cell death. In addition the multiparametric cytometric analysis, performed on an important number of cells, clearly showed that dead cells (FDA negative) were not apoptotic (sub-G1 DNA content) and found necrotic by other criteria ${ }^{21}$ and by morphology. Consistent with its inability to maintain viability, zVAD-fmk was unable to counteract mitochondrial alterations (according to $\Delta \Psi \mathrm{m}$ and GSH levels) exhibited by apoptotic cells. It must be noted that a loss of $\Delta \Psi \mathrm{m}$ and low GSH levels were similarly observed in $\mathrm{H}_{2} \mathrm{O}_{2}$-induced necrotic cells and, thus, were not specific for apoptotic cell death.

It is becoming evident that caspase inhibition is not sufficient to avoid the commitment to death. ${ }^{15}$ However, zVAD-fmk was also shown to block the reduction of $\Delta \Psi \mathrm{m}$ in a number of systems, including death receptor-induced apoptosis. $^{32,38,39}$ In another experimental system, zVADfmk led either to rescue from apoptosis or to another form of cell death according to the stimuli used to trigger apoptosis. Thus, pretreatment of Jurkat cells with zVADfmk inhibited anti-CD95 mAb triggered apoptosis, but not drug-induced apoptosis, with actual cell survival and maintenance of clonogenic potential, suggesting caspasedependent or caspase-independent commitment to cell death, according to circumstances. ${ }^{40}$ This could provide an explanation for the opposite results concerning the consequences of caspase inhibition. However, in the present study, zVAD-fmk partly protected thymocytes from spontaneous and from dexamethasone-induced apoptosis while it totally failed to prevent the commitment to cell death in similarly treated $B$ cells. This suggests that the signaling pathway to death decision is also cell specific.

In agreement with recent findings showing that caspase inhibitors were unable to fully restore cell viability in thymocytes, rather leading to necrosis, ${ }^{31}$ we observed that zVAD-fmk led partly to deviation from apoptosis to necrosis and partly to actual survival. The reason why a population of thymocytes was protected from cell death for a longer time is at present not well understood. Since those thymocytes which were saved from apoptosis presented normal $\Delta \Psi \mathrm{m}$ and high GSH levels, it must be admitted that caspases, which can be activated as a consequence of mitochondrial dysfunction, could themselves contribute to mitochondrial failure. A recent study on the specific role played by each caspase in the protease cascade involved in the execution of Fas-induced cell death in Jurkat cells indicated that a caspase, distinct from caspase-3 and -6, leads to the disruption of $\Delta \Psi \mathrm{m} .{ }^{41}$ However, in a cell-free system, caspase-1, -2, -3, -4, -6 were reported to cause the loss of $\Delta \Psi \mathrm{m}$ in isolated mitochondria. ${ }^{42}$ It thus appears that the mechanisms involved in the control of cell death greatly depend on experimental conditions.
Altogether, this study extends our previous findings by demonstrating that mitochondrial alterations are common and irreversible events in the commitment to cell death, whether the issue is necrosis or caspase-dependent apoptosis, and that IL-4 by countering early mitochondrial dysfunctions provides an anti-apoptotic and real survival signal.

\section{Materials and methods}

\section{Materials}

The culture medium used throughout was RPMI 1640 supplemented with $25 \mathrm{mM}$ HEPES, $2 \mathrm{mM}$ L-glutamine, standard antibiotics, $50 \mu \mathrm{M} 2$ mercaptoethanol and $8 \%$ heat-inactivated fetal calf serum (Biomedia, France). The caspase inhibitor benzyloxycarbonyl-Val-Ala-Asp(OMe)-fluoromethylketone (zVAD-fmk) was from Bachem Biochimie (France). The caspase substrate DEVD-pNA was from Alexis Biochemicals (Coger, France). Dexamethasone (DEX), 6-diamidino2-phenylindol (DAPI), fluorescein diacetate (FDA), ethidium bromide (EtBr), hydrogen peroxide $\left(\mathrm{H}_{2} \mathrm{O}_{2}\right)$ were from Sigma (St Louis, $\mathrm{MO}$, USA). 3,3'-dihexyloxacarbocyanine iodide $\left[\mathrm{DiOC}_{6}(3)\right]$ and monochlorobimane (MCB) were from Molecular Probes (Eugene, OR, USA).

\section{Cell preparation and culture}

Female C57BL/6 mice were purchased at 6-8 weeks of age (Iffa Credo, France). Mature B lymphocytes were purified as previously described. ${ }^{27}$ Briefly, splenocytes $\left(3-4 \times 10^{6} \mathrm{ml}^{-1}\right)$ were treated with anti-Thy 1.2 (CD90) monoclonal antibodies at $4^{\circ} \mathrm{C}$ for $30 \mathrm{~min}$ followed by incubation with Low-Tox rabbit complement at $37^{\circ} \mathrm{C}$ for $30 \mathrm{~min}$ (Cedarlane, Canada). Cells recovered at the $55-70 \%$ interface of a discontinuous Percoll gradient were characterized as B lymphocytes by IgM expression. Thymocytes were obtained by dilaceration of

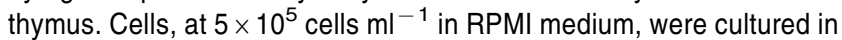
the presence or absence of stimuli as indicated in 24-well plates in $6 \%$ $\mathrm{CO}_{2}$ at $37^{\circ} \mathrm{C}$. For cytometric analysis, cells were fixed in $70 \%$ ethanol and kept at $-20^{\circ} \mathrm{C}$ until analysis of DNA content.

\section{Cell-staining for morphologic analysis}

Cells $\left(10^{6}\right.$ cells $\left./ 0.1 \mathrm{ml}\right)$ were washed with PBS and then stained with FDA $(1 \mu \mathrm{g} / \mathrm{ml})$ and $\mathrm{EtBr}(10 \mu \mathrm{g} / \mathrm{ml})$ for $5 \mathrm{~min}$ at $37^{\circ} \mathrm{C}$. FDA is cleaved into green fluorescein by intracellular esterases present in living cells, while $\mathrm{EtBr}$, a non-specific DNA intercaling agent, is taken up by dead cells. ${ }^{43}$ Quantitative analysis of each population was performed by counting more than 500 cells discriminated as viable cells (green fluorescence and nonstained normal nucleus), apoptotic cells (red condensed or fragmented nucleus) and necrotic cells (red 'apparently normal' or patchy nucleus). The results are presented as the mean of three experiments.

\section{Analysis of DNA fragmentation in agarose gels}

DNA from $5 \times 10^{5}$ cells was extracted as previously described. ${ }^{44}$ Briefly, after cell lysis, DNA was extracted and precipitated with $70 \%$ ethanol at $-20^{\circ} \mathrm{C}$ overnight. Electrophoresis was performed in $1 \%$ agarose gel containing $1 \mu \mathrm{g} / \mathrm{ml}$ ethidium bromide. DNA was visualized in UV light. $\phi \mathrm{X} 174 \mathrm{RF} /$ Haell digest was used as DNA size marker. 


\section{Caspase assay}

Cells $\left(5 \times 10^{6}\right)$ were cultured for $8 \mathrm{~h}$ in the presence or absence of drugs, as indicated and then washed and lysed in Triton X-100 buffer $(0.5 \%$ Triton X-100, 2 mM EDTA, $1 \mathrm{mM}$ PMSF) for 20 min on ice. Cell lysates were added with $0.5 \mathrm{ml}$ of ICE buffer (100 mM HEPES-KOH pH 7.5, $10 \%$ sucrose, $10 \mathrm{mM}$ DTT and $0.1 \%$ CHAPS) containing $100 \mu \mathrm{M}$ DEVD-pNA caspase substrate, and then incubated for $8 \mathrm{~h}$ at $37^{\circ} \mathrm{C}$. Enzyme-catalyzed release of $p$-nitroanilide was monitored at $405 \mathrm{~nm}$.

\section{Flow cytometryic analysis}

Fixed cells $\left(5 \times 10^{5}\right.$ cells $\left.\mathrm{ml}^{-1}\right)$ were washed twice with HBSS and then stained with DAPI $(2.5 \mu \mathrm{g} / \mathrm{ml})$ at $37^{\circ} \mathrm{C}$ for $20 \mathrm{~min}$. DNA content was quantified by flow cytometric analysis performed on a PARTEC CA II flow cytometer (Chemunex France) equipped with a $100 \mathrm{~W}$ mercury lamp (type HBO). Fluorescence at $455 \mathrm{~nm}$ was recorded as a function of DNA content. Each histogram was generated until the analysis reached at least $10^{4}$ cells. The percentage of apoptosis was determined from the sub-G1 events.

Mitochondrial transmembrane potential $(\Delta \Psi \mathrm{m})$ and intracellular reduced gluthatione (GSH) levels were measured as previously described. ${ }^{45} \Delta \Psi \mathrm{m}$ was determined by retention of $\mathrm{DiOC}_{6}(3)$, a cell permeant, cationic lipophilic fluorochrome which specifically accumulates into mitochondria according to $\Delta \Psi \mathrm{m}$. Cell staining was performed by treating cells $\left(5 \times 10^{5} \mathrm{ml}^{-1}\right)$ with $\operatorname{DiOC}_{6}(3)(0.1 \mu \mathrm{M})$ for $20 \mathrm{~min}$ at $37^{\circ} \mathrm{C}$. GSH levels were assessed using a specific cell permeant probe, MCB, which forms a fluorescent compound upon interaction with GSH, cells were treated with $\mathrm{MCB}(50 \mu \mathrm{M})$ for $20 \mathrm{~min}$ at $37^{\circ} \mathrm{C}$. Flow cytometric measurements were performed on an ELITE ESP flow cytometer (Coulter France). Fluorescence excitation was obtained through the blue line $(488 \mathrm{~nm})$ of an argon ion laser operating at $15 \mathrm{~mW}$. Green fluorescence of $\mathrm{DiOC}_{6}(3)$ was collected with a $525 \mathrm{~nm}$ band pass filter. A $100 \mathrm{~mW}$ UV excitation $(356 \mathrm{~nm})$ from a laser (INOVA 305, coherent) was used for quantification of [GSH/MCB] fluorescence integrated above $457 \mathrm{~nm}$. Analyses were performed on $10^{4}$ cells in list mode. Light scatter values were measured on a linear scale of 64 channels and fluorescence intensity on a logarithmic scale of four decades of log.

\section{Acknowledgements}

We thank Dr. Spencer Brown for helpful discussion and critical review of the manuscript and Mrs Nicole Esquirol for expert technical assistance. This work was supported by Paris-Sud University and the Centre National de la Recherche Scientifique (CNRS).

\section{References}

1. Raff M (1998) Cell suicide for beginners. Nature 396: 119-122

2. Golstein P, Ojcius DM and Young JD-E (1991) Cell death mechanisms and the immune system. Immunol. Rev. 121: 29-65

3. Cohen JJ, Duke RC, Fadok VA and Sellins KS (1992) Apoptosis and programmed cell death in immunity. Annu. Rev. Immunol. 10: 267-293

4. Kerr JFR, Wyllie AH and Currie AR (1972) Apoptosis: a basic biological phenomenon with wide ranging implications in tissue kinetics. Brit. J. Cancer 26: 239-257

5. Wyllie AH, Kerr JFR and Currie AR (1980) Cell death: the signifiance of apoptosis. Int. Rev. Cytol. 68: 251-305

6. Darzynkiewicz Z, Juan G, Li X, Gorczyca W, Murakami T and Traganos F (1997) Cytometry in cell necrobiology: Analysis of apoptosis and accidental cell death (Necrosis). Cytometry 27: 1-20
7. Alnemri ES (1997) Mammalian cell death proteases: A family of highly conserved aspartate specific cysteine proteases. J. Cell. Biochem. 64: 33-42

8. Cohen GM (1997) Caspases: the executioners of apoptosis. Biochem. J.326: 1 16

9. Thompson CB (1998) Apoptosis in the pathogenesis and treatment of disease. Science 267: $1456-1462$

10. Thornberry NA and Lazebnik Y (1998) Caspases: Enemies within. Science 281: $1312-1316$

11. Kroemer G, Zamzami N and Susin SA (1997) Mitochondrial control of apoptosis. Immunol. Today 18: 44-51

12. Green D and Kroemer G(1998) The central executioners of apoptosis: caspases or mitochondria? Trends Cell Biol. 8: 267-271

13. Mignotte B and Vayssiere JL (1998) Mitochondria and apoptosis. Eur. J. Biochem. 252: $1-15$

14. Bossy-WetzelE, NewmeyerDD and Green DR(1998) Mitochondrial cytochrome c release in apoptosis occurs upstream of DEVD-specific caspase activation and independently of mitochondrial transmembrane depolarization. EMBO J. 17: $37-49$

15. Green DR (1998) Apoptotic pathways: The roads to ruin. Cell 94: 695-698

16. Zamzami N, Susin SA, Marchetti P, Hirsch T, Gomez Monterrey I, Castedo Mand Kroemer G (1996) Mitochondrial control of nuclear apoptosis. J. Exp. Med. 183: $1533-1544$

17. Longthorne VL and Williams GT (1997) Caspase activity is required for commitment to Fas-mediated apoptosis. EMBO J. 16: 3805-3812

18. McCarthy NJ, Whyte MK, Gilbert CS and Evan GI (1997) Inhibition of Ced-3/ICErelated proteases does not prevent cell death induced by oncogenes, DNA damage, or the Bcl-2 homologue Bak. J. Cell. Biol. 136: 215-227

19. Ohta T, Kinoshita T, Naito M, Nozaki T, Masutani M, Tsuruo T and Miyajima A (1997) Requirement of caspase-3/CPP32 protease cascade for apoptotic death following cytokine deprivation in haematopoietic cells. J. Biol. Chem. 272: $23111-23116$

20. Kroemer G, Dallaporta B and Rescherigon M (1998) The mitochondrial death/life regulator in apoptosis and necrosis. Annu. Rev. Physiol. 60: 619-642

21. Lemaire C, Andréau K, Souvannavong V and Adam A (1998) Inhibition of caspase activity induces a switch from apoptosis to necrosis. FEBS Lett. 425: 266-270

22. Green DR and Reed JC (1998) Mitochondria and apoptosis. Science 281: $1309-1312$

23. Illera VA, Perandones CE, Stunz LL, Mower DAJ and Ashman RF (1993) Apoptosis in splenic B lymphocytes. Regulation by protein kinase $\mathrm{C}$ and IL-4. J. Immunol. 151: 2965-2973

24. Baixeras E, Bosca L, Stauber C, Gonzalez A, Carrera AC, Gonzalo JA and Martineza C (1994) From apoptosis to autoimmunity: Insights from the signaling pathways leading to proliferation or to programmed cell death. Immunol. Rev. 142: $53-91$

25. Paul WE (1991) Interleukin 4: a prototypic immunoregulatory lymphokine. Blood $77: 1859-1870$

26. Norvell A, Mandik L and Monroe JG (1995) Engagement of the antigen-receptor on immature murine B lymphocytes results in death by apoptosis. J. Immunol. 154: $4404-4413$

27. Souvannavong V, Lemaire C, Andréau K, Brown S and Adam A (1998) Ageassociated modulation of apoptosis and activation in murine $B$ lymphocytes. Mech. Ageing Dev. 103: 285-299

28. Bellosillo B, Dalmau M, Colomer D and Gil J (1997) Involvement of CED-3/ICE proteases in the apoptosis of B-chronic lymphocytic leukemia cells. Blood 89: 3378-3384

29. Parry SL, Hasbold J, Holman M and Klaus GGB (1994) Hypercross-linking surface IgM or IgD receptors on mature B cells induces apoptosis that is reversed by costimulation with IL-4 and anti-CD40. J. Immunol. 152: 2821-2829

30. Foote LC, Howard RG, Marshakrothstein A and Rothstein TL (1996) IL-4 induces Fas resistance in B cells. J. Immunol. 157: 2749-2753

31. Hirsch T, Marchetti P, Susin SA, Dallaporta B, Zamzami N, Marzo I, Geuskens M and Kroemer G (1997) The apoptosis-necrosis paradox. Apoptogenic proteases activated after mitochondrial permeability transition determine the mode of cell death. Oncogene 15: 1573-1581

32. Nicholson DW, All A, Thornberry NA, Vaillancourt JP, Ding CK, Gallant M, Gareau Y, Griffin PR, Labelle M, Lazebnik YA, Munday NA, Raju SM, Smulson ME, Yamin T, Yu VL and Miller DK (1995) Identification and inhibition of the ICE/ CED-3 protease necessary for mammalian apoptosis. Nature 376 : $37-43$ 
33. Zamorano J, Wang HY, Wang LM, Pierce JH and Keegan AD (1996) II-4 protects cells from apoptosis via the insulin receptor substrate pathway and a second independent signaling pathway. J. Immunol. 157: 4926-4934

34. He HL, Hershberger PA and McCarthy SA (1998) Down-modulation of a novel Bax-associated protein during apoptosis in normal mature B lymphocytes. J. Immunol. 161: 1176-1182

35. Beaver JP and Waring P (1995) A decrease in intracellular glutathione concentration precedes the onset of apoptosis in murine thymocytes. Eur. J. Cell Biol. 68: 47-54

36. Marchetti P, Hirsch T, Zamzami N, Castedo M, Decaudin D, Susin SA, Masse B and Kroemer $\mathrm{G}$ (1996) Mitochondrial permeability transition triggers lymphocyte apoptosis. J. Immunol. 157: 4830-4836

37. Hirsch T, Dallaporta B, Zamzami N, Susin SA, Ravagnan L, Marzo I, Brenner C and Kroemer $G$ (1998) Proteasome activation occurs at an early, premitochondrial step of thymocyte apoptosis. J. Immunol. 161: 35-40

38. Boise LH and Thompson CB (1996) Hierarchical control of lymphocyte survival. Science 274: 67-68

39. Armstrong RC, Aja TJ, Hoang KD, Gaur S, Bai X, Alnemri ES, Litwack G, Karanewsky DS, Fritz LC and Tomaselli KJ (1997) Activation of the CED3/ICE related protease CPP32 in cerebellar granule neurons undergoing apoptosis but not necrosis. J. Neurosci. 17: 553-562
40. Amarantemendes GP, Finucane DM, Martin SJ, Cotter TG, Salvesen GS and Green DR (1998) Anti-apoptotic oncogenes prevent caspase-dependent and independent commitment for cell death. Cell Death Differ. 5: 298-306

41. Hirata H, Takahashi A, Kobayashi S, Yonehara S, Sawai H, Okazaki T, Yamamoto K and Sasada M (1998) Caspases are activated in a branched protease cascade and control distinct downstream processes in Fas-induced apoptosis. J. Exp. Med. 187: 587-600

42. Marzo I, Brenner C, Zamzami N, Susin SA, Beutner G, Brdiczka D, Remy R, Xie ZH, Reed JC and Kroemer G (1998) The permeability transition pore complex: A target for apoptosis regulation by caspases and Bcl-2-related proteins. J. Exp. Med. 187: 1261-1271

43. Jones KH and Senft JA (1985) An improved method to determine cell viability by simultaneous staining with fluorescein diacetate-propidium iodide. J. Histochem. Cytochem. 33: 77-79

44. Sarih M, Souvannavong V and Adam A (1993) Nitric oxide synthase induces macrophage death by apoptosis. Biochem. Biophys. Res. Commun. 191: 503508

45. Sidoti-de Fraisse C, Rincheval V, Risler Y, Mignotte B and Vayssiere JL (1998) TNF-alpha activates at least two apoptotic signaling cascades. Oncogene 17: $1639-1651$ 